\title{
SATIRIC LYRIC? HORACE ODES 3.7-12
}

\section{S Thom (University of Stellenbosch)}

A cluster of six poems, Odes 3. 7-12, enhanced by their position in the collection of Odes (following as they do the Roman Odes, Odes 3. 1-6) seems to stake Horace's claim as a poet of personal relationships to the same extent that the Parade Odes (Odes 1. 1-9) staked his claim as a master craftsman. ${ }^{1}$ Nowhere else in the collection do we have such a large group of poems dedicated exclusively to expressing aspects of personal relationships. ${ }^{2}$ In addition, it is striking that the group as a whole also seems to focus on ironic points of view on the situations concerned. The most obvious explanation for this special focus could lie in the fact that the poems are meant to be read as a group, which in turn requires that the perspective reflected by the group as a whole should be taken into careful consideration.

lyric poems: the perspectives reflected in these odes have much more in common with the One thing becomes strikingly clear in a closer analysis of individual odes in this cluster of exaggeration and critical spirit normally associated with the satirist than the stereotypical viewpoint expected from the traditional lyric poet. ${ }^{3}$ The satirist depends on the firm backdrop of a shared reality against which subtle differences from or exaggerations of the norm become obvious to the reader. ${ }^{4}$ If lyric poetry's most fundamental quality is a focus on the personal, on real problems and real situations as experienced by the protagonist reflected in a specific poem (Porter 1987:172) satiric lyric incorporates a confident, ironic perspective on the personal situation concerned that reflects a critical spirit not traditionally associated with lyric poetry. The real problem as well as the real situation in the lyric poem "is no longer what it seems" (Gowers 1993:220). Against the firm backdrop of the lyric reality, the constantly shift of focus reflected in each poem in Odes 3.7-12 suggests a satiric spirit, an association with satire, not traditionally found in lyric poetry. ${ }^{5}$ To acknowledge the satiric perspective is to enhance the meaning of the lyric fundamentals of the poem. ${ }^{6}$

1. Contra Syndikus who calls them rather light-weight (1990:98).

2. See Santirocco (1986), Dettmer (1983) and Commager (1962) for discussions on different groupings of poems in Horace's Odes.

3. The stereotypical viewpoint concerned reflects content, not form. Cf Porter (1987:172) who insists on lyric poetry's "persistent emphasis on facing real problems and real situations" (my italics). See also note 5 below. The most basic difference between a lyric focus on the real and a satiric perspective of the same situation is the acknowledgement that no single perspective could represent the multi-facetted point of view associated with satire. A satiric perspective would therefore enlarge the intent reflected by the stereotypical lyric content of a poem.

4. See Freudenburg's analysis of how imagery and diction can conspire to suggest that an object can represent much more than it presents (1992:190). See also Gowers's statement on invitation poems where an object (in this case a loaded table) "is no longer what it seems. Lurking under the heavy weight of material are more abstract notions of style ..." (1993:220).

5. See Zetzel's description of satire where "every statement of almost any kind is suspect, owing to the constant irony and self-contradictions of the speaker's voice" (2002:39).

6. Needless to say, I am not making a case for lyric poetry to be reclassified as satire when lyric poetry employs satiric overtones. I am making a case for understanding satire as satire even when a lyric poem is the vehicle. In other words, a lyric poem can be read as lyric, but in addition to its being a lyric poem, it could also represent a staunchly satiric perspective that, at the same time, enhances and undermines the original meaning — to the delight of the reader as well as the poet-persona. 
I do not suggest that Horace is promoting the qualities of satire as preferable to those of lyric - not even under lyric guise. ${ }^{7}$ I do suggest, however, that this group of poems can be classified as a group because they reflect the same critical focus on changing perspectives associated with satire. ${ }^{8}$ I further suggest that an awareness of the satirical overtones of these poems as a group enhances the reader's understanding of the poems in a specific way. In short, in this paper I want to point out the specific gain in our understanding of six of Horace's lyric poems if their satiric overtones are acknowledged and taken into account collectively, instead of as examples of a number of rhetorical devices (such as irony, exaggeration, etc.) used to enhance the lyric perspective reflected by the poems. ${ }^{9}$ Horace, after all, is a lyric poet who would frequently be better understood if his satiric perspective on life is acknowledged. ${ }^{10}$

After six poems in the Alcaic metre, Odes 3.7's initial "what are you crying for, Asterie?" (quid fles Asterie, 3.7.1) in the fourth Asclepiad comes as a striking change. ${ }^{11}$ The reader could certainly understand Asterie to "cry for Rome" (Collinge 1961:51; Commager 1962:16). It soon becomes clear, however, that social conditions and the world of politics have been pushed aside firmly. ${ }^{12}$ Asterie's crying is not caused by that exemplary lover Gyges either - Gyges is in no real physical, financial or even emotional danger. In spite of the insidious temptations confronting him, Gyges's tears match those of his beloved Asterie (frigidas noctes non sine multis insomnis lacrimis agit, 3.7. 6-8). The poem seems to affirm Gyges's constancy even before it dwells on the temptations facing him (ignibus uri, temptat mille vafer modis, 3.7.11-12). By this direct contrast between Gyges's experience of the cold of circumstance (frigidas noctes, 3.7.6-7) and the heat (ignibus, 3.7.11) generated by the message of temptation, ${ }^{13}$ the reader is jolted into the realization that the perspective in this poem, as opposed to the preceding Roman Odes, is highly personal and even idiosyncratic. Asterie's crying is caused by her own perspective on a personal situation. ${ }^{14}$ The cluster of lyric poems in Odes 3.7-12 therefore starts by undermining the obvious preconceived perspective - that Asterie is crying for Rome - and points the reader firmly in the direction

7. See Barchiesi (2001:141) and Hinds (1998) on the "instability" reflected in the idea of genres.

8. After the Roman Odes where an "epic" situation in a group of poems was undermined consistently by a personal, lyric perspective (Thom 1998:52-66) it makes excellent artistic sense to hold the lyric perspective in a group of poems up to scrutiny in turn.

9. Since it is not the aim of this paper to argue in terms of lyric poetry as a genre as opposed to satire as a genre the traditional requirements for lyric and satire are accepted as a given.

10. Horace published his first opus under the title Sermones and all understood those "sermones" to refer to satires (Van Rooy 1965:66).

11. The uniformity of metre associated with the Roman Odes makes way for the following metres represented in this cluster: Odes 3.7: Fourth Asclepiad; Odes 3.8: Sapphic; Odes 3.9: Second Asclepiad; Odes 3.10: Third Asclepiad; Odes 3.11: Sapphic; Odes 3.12 Ionic a minore. See Seager (1993:27-28) on the abrupt change in tone reflected in this group of poems after the solemnity and the focus on social issues of the Roman Odes.

12. Cairns (1995: 66-99) gives an overview of the divergent scholarly opinion on this poem.

13. Cf. Paschalis (2002:75 n. 12) who discusses the metaphorical implications of heat and cold.

14. One of the fundamental perspectives which is first introduced and then debunked in Horace Odes 3.7 is the elegiac perspective (Cairns 1995:70). This paper, however, will not concentrate on the somewhat circumscribed prerequisits for elegy, but rather on the multi-facetted point of view, which is the hallmark of satire. 
not of one but of a variety of alternatives. ${ }^{15}$ Right at the beginning of this cluster of poems, the single-minded lyric focus (representing one person's perspective on her own personal situation) is undermined by pointing out the satiric alternative: reality is not always what it seems (Gowers 1993:220). A variety of alternative perspectives on the same situation is not only possible but, ironically, more realistic. Against the firm backdrop of the lyric reality, this shift in focus reflects a satiric spirit not traditionally found in lyric poetry.

The first alternative, that Asterie is not crying for Rome, but rather for herself, seems to represent the typical lyric predicament of a lover bewailing the absent beloved. According to the first three stanzas of Odes 3. 7 Asterie is crying for her distant beloved Gyges with good reason. Gyges is being seriously tempted by his seductive hostess, Chloe, by means of her rather persuasive go-between (nuntius . . . sollicitae hospitae, 3.7.9). This sets the stage for the traditional love triangle that never seems to work out satisfactorily in Horace. ${ }^{16}$

The middle section of the poem (stanzas 4-5) reports the pressures brought to bear on Gyges to succumb. Two very interesting mythological examples are brought into play at this crucial stage. These are examples where the hero did not give in to temptation but, ironically, in the end suffered as if he had. Bellerophon is killed and Peleus just misses being killed, because of morally "correct" choices. ${ }^{17}$ In both examples retribution is exacted just as if the tempted person had indeed succumbed, implying that there is little personal advantage to be had from the moral high ground. In myth these examples illustrate the price to be paid for acting honourably. In the ordinary world it illustrates the consequences of not understanding expediency.

However, the shifting perspective encapsulated in the examples from myth subtly changes the focus of the poem. It is no longer a question of Asterie's crying for her absent beloved, who may or who may not be in physical or moral danger. The poem has now turned its attention from the (ostensibly) threatened lyric relationship to the real world of relationships, where Gyges's constancy in spite of being under threat, triumphs "up to now" (adhuc integer, $3.7 .22) .{ }^{18}$

It is striking that the two double-edged mythological examples (stanzas 4 and 5) form the bridge between the ostensible setting of the poem (stanzas 1-3) and the real situation (stanzas 6-8). The ostensible love triangle is represented by the heartbroken Asterie, the sorely tempted Gyges and the apparently successful rival Chloe. In the real situation (stanzas 6-8), however, Asterie, not Gyges, is tempted. ${ }^{19}$ Her temptation is much more difficult to withstand, since she is not tempted by a go-between with ingeniously manipulated mythical

15. Contra Cairns (1995:66) who reduces the poem to "views" on Asterie and Gyges. Asterie is either not to be taken seriously and the situation between her and Gyges is to be read as "light relief after the solemnity of the 'Roman Odes"' (1995:66), or the poem reflects a marriage in jeopardy reminding the reader of the "emphasis on marriage in the "Roman Odes"” (1995:66).

16. Assessing Horace as a love poet often seems to depend on whether he is seen as a failed "romantic" or a rather detached realist. Such personal perspectives on the poet have subtly influenced or even undermined critical readings of his love poetry. For example, a critic of the calibre of Ancona has suggested that gender awareness in general and the male's effort "to control the temporality of the beloved" (Ancona 1994:14) should inform the critics' reading of Horace's perspective as reflected in his love poetry.

17. For instance, Bellerophon's stepmother's misguided attempts to tempt him may fail morally — the woman being underhand (perfida, 3.7.13) and the charges false (falsis criminibus, 3.7.14) — but they succeed in the sense that they cause retribution to be exacted just as if he had given in to those temptations.

18. The use of adhuc implies that the future remains open, but at least there is no reason for regret, yet.

19. Cf. Davis (1991:47) who underlines the analogy between the two situations of temptation. 
examples, but rather by the immediate physical presence and prowess of her neighbour Enipeus.

Why is Asterie crying then $2^{20}$ The perspective reflected in the myths seems to suggest Asterie is crying for herself. She is in exactly the same position as Gyges, far away from her beloved, but in very close contact with serious temptation. This is no one-dimensional perspective on time, gender, or relationships. ${ }^{21}$ By quoting the mythical examples to underline the exact opposite of the application normally associated with the stories (Bellerophon's probity and Peleus's abstinence), Horace seems to suggest that Asterie can be seen to be crying for the position in which she finds herself, not because of an unfaithful lover, but rather because of her own incipient faithlessness. By manipulating the perspective reflected in the myth to produce examples that incite wrong (docentes historias peccare, 3.7.19-20) rather than encourage right (fallax movet, 3.7.20) the poet seems to suggest that perspective is a highly individual characteristic. ${ }^{22}$ In other words the contrast between the myth's depiction of Bellerophon as a hero and the go-between's assessment of him as a fool, is largely a matter of perspective. Asterie too has to choose her own perspective on a situation, which could turn her into a hero or a fool.

By inserting this mythological manipulation of perspective right in the middle of the poem, Horace suggests the complexity and ambiguity of perspective. This is not the simple perspective stereotypically associated with the lyric point of view. It is a highly sophisticated and critical perspective on a situation, the type of perspective typically associated with a satiric view of things. Initially it seems as if Asterie is crying because of Cloe's threat to her relationship with Gyges. If this threat is removed (or shown to be unrealistic) Asterie should stop crying. But Asterie faces two potential love triangles, not one. In the one she could be the passive, scorned beloved - the victim of infidelity. In the other she could become the actively scorning lover - the perpetrator of infidelity. Asterie's crying is therefore no simple matter. It is the result of her understanding of a complex and ambiguous human situation. Furthermore, the luxury of blaming the other party is no longer an option. The direct parallel between what she anticipates happening to Gyges and her own seduction by Enipeus shows up any pretence she might have had of blaming Gyges.

At the end of the poem the reader has come to understand that it is not the situation or the choices facing Asterie that cause her crying, but the multiplicity of possibilities associated with the situation. In spite of ostensibly having made the "right" choices, Bellerophon and Peleus suffered as if they had made morally wrong choices. Asterie seems to be facing the same realization. A simplistic understanding of the traditional lyric situation (where she is the alleged victim) has to make way for the more realistic and less naive understanding of the situation (where she could be either victim or perpetrator) associated with satire. The perspective reflected in the myth implies that the consequences of whatever she chooses to do

20. Note that no direct answer is given to this question. Cf. Martin (2002:111-113) who refers to "the real-time technique of the "silent answer" in his discussion of such answers in Horace Odes 1.27.

21. It must be clear that Asterie is also crying because the easy way out - blaming an inconstant beloved - is no longer an option. Connor (1987:180) indicates "sharp criticism" of Asterie's real inclination in the poem.

22. Davis (1991:48-49) describes the shift as a "duplicitous appropriation" of the temptation of heroic figures in "the interest of an immoral liaison." 
might well turn out to be negative.$^{23}$ Asterie is faced with the final realization that life is more complex than she thought. ${ }^{24}$

One can describe this unexpected final perspective as a typical lyric ploy to represent lovers eternally separated by circumstance. On the other hand one could also acknowledge a serious didactic purpose in representing such a medley of perspectives of the same situation. A situation typical in lyric poetry has been undermined by serious scrutiny. A satiric tone is overriding the lyric voice. ${ }^{25}$

Odes 3.8 too, focuses on and plays with different perspectives, as the introductory reference to the anomaly of a bachelor celebrating a spring fertility feast indicates (martiis caelebs quid agam kalendis, 3.8.1). ${ }^{26}$ In this poem Horace manipulates the anomaly of contradicting perspectives on the same situation to persuade Maecenas to share in the exuberance of his own very different perspective on time and responsibility (dona praesentis cape laetus horae ac linque severa, 3.8.27-28). ${ }^{27}$

The Kalends of March, an official fertility feast, is normally celebrated only by women. ${ }^{28}$ Horace, who is neither female nor celebrating this specific feast, is nevertheless celebrating. The same feast day can represent a public as well as a private celebration. Having deconstructed, as it were, the cause and the celebrants (in fact everything associated with this feast, except its date) Horace is ready to supply a new cause and alternative celebrants. Instead of the public feast celebrating women, there will be a private feast celebrating Horace's escape from a fallen tree (prope funeratus arboris ictu, 3.8.7-8). Instead of official celebrants there will be two private citizens, Horace and his friend Maecenas. The point of the deconstruction is of course that Maecenas cannot deny that the day is a designated feast day. And once Horace has put forward the personal alternatives to the official celebrations, Maecenas would be hard put not to share Horace's perspective.

In spite of the light-hearted manipulation of perspective in this poem, fundamental contrasts associated with and represented in different perspectives are again underlined. The poem can only work when Maecenas (as well as the reader) acknowledges that the same thing can mean different things to different people depending on individual perspective. We can read the poem as a simple and exuberant lyric invitation to a friend to celebrate the beginning of spring (sume, Maecenas, cyathos amici sospitis centum, 3.8.13-14). We can also read the poem as a satiric send-up and humorous criticism of an over-worked

23. Contra Ancona (1994:22-23) who points to “. . . a temporal predicament in which lover and beloved seem equally enmeshed. However, their differing relationships to time will reveal yet another example of the hierarchical and gendered distinctions between male lover and female beloved" (1994:22-23). The implications underscored by the use of the mythic exempla, however, argues against these "hierarchical and gendered distinctions" since both myths incorporate an alternative, more realistic, if distinctly unheroic, female perspective borne out in the negative consequences associated with the heroic choice.

24. In effect the poem implies that she is crying for the lost innocence of a simple understanding of the situation where an awareness of the multiplicity of possibilities associated with that situation undermines the ability to act.

25. I have analysed the basis for acknowledging the satiric interpretative possibilities of this first poem in the cluster in great detail. In the next five poems I shall point out the satiric overtones much more cursorily.

26. Santirocco (1986:125) maintains that the "intrusion of C.3.8 into an otherwise erotic sequence is not satisfactorily explained." If, however, the cluster is taken as poems reflecting personal relationships and the general purpose of the cluster is understood as holding lyric perspective up to satiric scrutiny, there is no question of "intrusion."

27. See Connor's excellent analysis of Maecenas's response to Horace's preparations (1987:121-124).

28. According to Griffin (1997:54-69) Horace appears to be celebrating the Matronalia. 
government official who takes himself too seriously (parce privatus nimium cavere, 3.8.26) (Seager 1993:33). The satiric reversal of the lyric environment is clear.

The importance of this reversal though lies in the pressure brought to bear on Maecenas to accept the invitation. He might be able to refuse an invitation given within lyric parameters. This poem, however, has already discounted that possibility, by undermining these lyric parameters. By accepting the invitation, Maecenas admits Horace's reading of the situation: that he is an overworked government official who takes himself too seriously. By accepting Horace's invitation, however, Maecenas in turn undermines the criticism implied by the satiric perspective on him. ${ }^{29}$ A satiric tone is again breaking through in spite of the lyric voice — and to the advantage of the lyric point of view.

Odes 3.9 celebrates changing perspectives. A changing perspective on time (past, present and future) as well as a constantly changing point of view (reflected in the statement and response structure of the poem) underpins the whole. Apart from the obvious contrasts between male, female, lover and beloved (in all its configurations in the past, present and future) the most persuasive contrast is that encapsulated in a "romantic" vs. realistic perspective on the whole.

To a certain extent the more romantic perspective is represented by the male who describes himself and his situation in terms of the unfamiliar and exotic, for instance he is supposedly more blessed than the king of the Persians (Persarum vigui rege beatior, 3.9.4) while his present beloved is from remote Thrace (me nunc Thressa Chloe regit, 3.9.9). ${ }^{30}$ The more realistic female perspective is firmly rooted in the familiar: her frame of reference is her own reputation (multi Lydia nominis, 3.9.7) which surpasses that of Rhea Silvia while her socalled beloved, Calais, is introduced in terms of his identifiable family origin and home (Thurini Calais filius Ornyti, 3.9.14). ${ }^{31}$

Normally the rapprochement needed for reconciliation between injured parties is associated with a more romantic (and often more gullible) partner rather than to be looked for in a lover who is realistically aware of any number of the beloved's unpleasant character traits. In Odes 3.9 however, it is Lydia's realistic and completely down to earth assessment of her beloved as flighty and irascible (tu levior cortice et improbo iracundior Hadria, 3.9.2223) that persuades the reader of the possibility of a happy ending to the story. ${ }^{32}$ Since her perspective has already taken his instability and grouchiness into account, the basis for the relationship seems much more secure.

In consistently switching between the male and female perspective throughout the poem, the poet encourages the reader to be sensitive to more than one perspective on a specific situation. ${ }^{33}$ In this poem the traditional male perspective of being more logical and more realistic is however, attributed to the female character while the traditionally female instinctive and more romantic perspective is represented by the male. Horace uses this ironic

29. The criticism is after all that he, Maecenas, allows himself to be overworked and that this is only possible because he takes his own perspective on a situation as the only one possible. The moment he admits that another perspective is valid, the criticism is void.

30. Syndikus (1990:111) argues that Horace is the man in the poem.

31. Putnam (1977:140) points out that Lydia "finds a likeness for herself not in some anonymous exotic king, devoted no doubt to a life of delicate abundance. Instead she opts for more immediate Roman Ilia whom all would know."

32. Contra Arkins (1993:117) who maintains "we do not believe" Lydia when she affirms " I'd love to live with you, I'd gladly die with you."'

33. Cf. the sensitive discussion of the poem by Putnam 1977:137-157. 
inversion of perspectives to undermine the seriousness of the poem. He is again in fact looking at a very common lyric situation from a strikingly satiric perspective - a perspective that turns normal lyric expectations upside down, whilst giving a humorous exposé of lyric convention.

At first glance Odes 3.10 seems to represent a traditional exclusus amator complaint against a heartless beloved, aiming to persuade her to change her mind. By the end of the poem a kaleidoscope of perspectives on this single situation has been put forward, while the traditional aim of the poem has been undermined as well.

Odes 3.10's Lyce is described not as she is, but as she would be if she were some distant barbarian's wife (extremum Tanain si biberes, Lyce, saevo nupta viro, 3.10.1-2). This woman would have felt compassion for the rejected lover exposed to the elements as presented in the poem (me tamen asperas porrectum ante fores obicere incolis plorares Aquilonibus, 3.102 4). Horace dwells on the extreme weather conditions (3.10. 5-8) to evoke a corresponding harshness of temperament in the people, just to invert this perspective completely. It is the supposedly harsh barbarian woman who feels compassion for the rejected lover. In comparison Lyce, who should respond more sympathetically, embodies a chill inhumanity.

The crux of the poem is reflected in the middle stanza (3.10. 9-12) where Lyce's untenable perspective is explained as due to pride (superbiam, 3.10.9). In this stanza Horace makes it clear that Lyce's disdain is not due to primitive insensitivity to the plight of others (that might have explained a barbarian woman's harsh attitude). Lyce's disdain springs from a false sense of her own superiority. This false sense of superiority is not only hateful to Venus (ingratam Veneri, 3.10.9), but also not based in reality. Lyce is no Penelope rejecting inopportune suitors, nor can she claim exceptional breeding (Tyrrhenus genuit parens, 3.10.12) for her haughty perspective. Lyce is no epic or elegiac heroine. Instead she has to come to terms with being a lyric protagonist who cannot justify her extremist position (nec rigida mollior aesculo, nec Mauris animum mitior anguibus, 3.10. 17-18). Since traditional persuasive measures such as gifts (munera, 3.10.13), pleas (preces, 3.10.13), compassion for the lovers' suffering (pallor amantium, 3.10.14) or even a husband's infidelity (vir Pieria paelice saucius curvat, 3.10.15-16) make no impression on Lyce's point of view, time will step in and change not only her perspective but the whole situation (non hoc semper erit . . .patiens latus, 3.10.19-20). ${ }^{34}$

The poem starts with a change of place (the barbarian hinterland as opposed to fashionable Rome) representing a different perspective. The poem ends with a change in time that encapsulates a final alternative perspective. Horace has previously used extreme realism to undermine the beloved's refusal to admit the excluded lover (Odes 1.25). The aim of the exclusus amator topos has always been, by whatever means possible, to persuade the beloved to admit the lover to her presence. However, the exclusus amator situation depending as it does on a disdainful mistress as well as on a lover-supplicant, ceases to exist not only when the mistress becomes willing (the traditional aim of the topos) but also when the lover withdraws his suit - as he threatens so unexpectedly in Odes 3.10. This is not the traditional lyric ending. Instead it is a suitably apt ending to a situation where pride informed one partner's perspective and traditional lyric expectations the other's. It is as if a satirist takes over the original lyric situation and turns it into an exposé of the folly often associated with (lyric) relationships.

34. Syndikus (1990:118) points out the "Elegie fremden Objektivität" of this description. 
In the first stanza of Odes 3.11 Horace, as he so often does, hands his reader a key to understanding the poem. Mercury is one of the addressees in the poem. ${ }^{35}$ Traditionally he is the trickster god who undermines the ordinary or normal perspective on reality.

The other addressee, the lyre, was once neither eloquent nor pleasing (nec loquax olim neque grata, 3.11.5). Now it is both persuasive and sought after (nunc et divitum mensis et amica templis, 3.11.5-6). The raw material involved did not change, but perspective on the lyre changed fundamentally.

The poem very carefully outlines the far-reaching power the lyre has achieved over both nature (3.11.13-14) and mythology (3.11.15-24) including access to the underworld (overcoming Cerberus). In itself therefore the lyre represents the result of a changed perspective on reality, achieved under the auspices of Mercury's influence.

In Odes 3.11 the lyre is evoked to act as an agent for a change of perspective. Lyde must be persuaded to listen properly to the lyric message (dic modos, Lyde, quibus obstinatas/ applicet aures, 3.11.7-8). ${ }^{36}$ Just like the lyre, Lyde too is connected firmly to nature and mythology. She is associated with nature when the first description of her places her playing in the fields like a young filly (quae velut latis equa trima campis ludit exsultim, 3.11.9-10). She is connected to mythology in the central stanza (7) where she is associated with the crime and punishment of Danaus's daughters (audiat Lyde scelus atque notas virginum poenas ... seraque fata . . 3.11.25-26, 28). She is warned implicitly that she too may suffer the same punishment, if she is guilty of the same crime. The daughters of Danaus, however, included one splendide mendax (3.11.35) daughter who saw her situation differently. The implication is that if Lyde too comes to see her situation differently, the lyre will celebrate her as a true lyric heroine. Like the lyre, she could become a symbol reflecting a different reality.

The point of the story surely lies in the overwhelming odds that only one out of fifty daughters managed to share the perspective put forward for Lyde to accept. Such odds undermine the very basis of the argument from the lyric perspective, where the possibility of Lyde's positive response is extolled, not its probable unrealistic outcome. The very fact that an insubstantial shadowy supplicant wants to persuade Lyde to act like the exception rather than the rule underpins the unrealistic expectations of the poem. Once again satiric overtones exploit a lyric situation by pointing out the inherent irony and complexity associated with the situation concerned, thereby enhancing the impact of the poem.

Neobule's song in Odes 3.12 brings to a close a cluster of poems (Odes 3.7-12) with a predominant focus on personal relationships. ${ }^{37}$ In addition this cluster of poems has concentrated on reflecting changing perspectives on those personal relationships. Neobule's assessment of her situation reflects yet another focus on perspective as well as bringing the cluster to a close by its reference (albeit in passing) to Bellerophon once again.

Horace has previously offered a number of possible "outcomes" to the exclusus amator situation. ${ }^{38}$ Most focused on the inevitable changes brought about by the passage of time (cf.

35. Cf. Bond (1986:68-86) for Horace's poetic association with Mercury.

36. Note that the supplicant is not described directly, nor is what he asks specified. Cf. Bradshaw (1978:156) who points out that there is no justification to claim Horace for the lover in the poem.

37. The Fons Bandusiae poem (Odes 3.13) assesses the contribution of art to life and by implication Horace's achievement as a poet, serving as yet another indication that the Roman odes (Odes 3.1-6) and the personal relationship poems (Odes 3.7-12) could be considered as two distinct groups.

38. Cf. Seager (1993:28) on the "matronly pursuits" encouraged by Augustus but shown to be completely ineffectual in the present situation. 
Odes $1.25,3.10)$. Neobule's situation embodies a different point of view: the changes brought about when a specific situation is simply seen from a different perspective, id est: that the prerequisites for an exclusus amator situation do not apply to Neobule's position since the socalled hard-hearted "lover" is simply not interested. Neobule represents the rejected lover whose beloved has neither the time nor the inclination to remedy the situation.

Fundamentally nothing changes in the poem - an aspect that is subtly but inexorably underlined by the poem's set metric pattern (Ionic a minore) that allows for no variations whatsoever. Neobule remains preoccupied with her situation ${ }^{39}$ and the well-oiled Hebrus, the love focus in the story, remains oblivously involved with his physical pursuits elsewhere. ${ }^{40}$ The ruthless tempo of the repetitive metre represents a kind of time loop. At the end of the poem the metre seems to force the reader to start all over again. The difference is that this time around the reader (and Neobule) has an ironic perspective on the whole. ${ }^{41}$ And this ironic perspective seems to incorporate a rather satiric take on human relationships: plus ça change, plus c'est la même chose!

I have argued elsewhere that Horace set up an epic perspective in the Roman Odes just to undercut this position by a lyric reassessment (Thom 1998:52-66). It seems to me as if he does the same in Odes 3.7-12, except that he sets up a lyric perspective which he undercuts by the multiplicity of perspectives so characteristic of the satirist.

This satiric awareness of change, small shifts in possible interpretation and the openendedness of human communication seem in themselves to underpin Horatian lyric to a larger extent than is often acknowledged. In the above six poems Horace successfully managed to push the boundaries of lyric expression by exploiting the satiric aspects evident in many facets of personal relationships. Those aspects are not traditionally celebrated by lyric poetry. In privileging a satiric perspective in a cluster of poems Horace has been able to reflect more than one, ambiguous or even contradictory perspective - consistently and with great sensitivity. In all of the above poems Horace took inordinate pains precisely not to reflect a consistent, a simplistic or even a stereotypical lyric perspective - to the advantage of the lyric poetry concerned.

\section{BIBLIOGRAPHY}

Ancona, R 1994. Time and the erotic in Horace's Odes. Durham: University of North Carolina.

Anderson, WS (ed.) 1999. Why Horace? A collection of interpretations. Wauconda: BolchazyCarducci

Arkins, B 1993. The cruel joke of Venus: Horace as love poet. In Rudd Horace 2000: A celebration. Essays for the bimillenium 106-119.

Barchiesi, A 2001. Horace and Iambos:The poet as literary historian. In Cavarzere, Aloni, Barchiesi (eds) Iambic Ideas: Essays on a poetic tradition from archaic Greece to the late Roman Empire 141-164.

Bond, R 1986. Dialectic, eclectic and myth (?) in Horace, Satires 2.6. Antichton 19:68-86.

Bradshaw, A 1978. Horace and the therapeutic myth. Odes 3.7, 3.11 and 3.27. Hermes 106:156-176.

39. Oliensis (1998:92) points to the "resonant phrase verbera linguae" in C.3.12.3 implying that words are the only weapon left to Neobule, both to counter her uncle's tongue-lashing and to come to terms with her own situation.

40. Cf. Leach (1994:338) for a discussion of the implications of such manly activities.

41. Contra Porter (1987:177) who describes Neobule as a "passive victim unable either to take the initiative or to give play to her feelings." 
Cairns, F 1995. Horace, Odes 3.7: Elegy, lyric, myth, learning and interpretation. In Harrison Homage to Horace: A bimillenary celebration 65-99.

Cavarzere, A, Aloni, A, Barchiesi, A, (eds.) 2001. Iambic Ideas: Essays on a poetic tradition from archaic Greece to the late Roman Empire. Oxford: Rowman \& Littlefield.

Commager, S 1962. The Odes of Horace. New Haven: Yale University Press.

Connor, P 1987. Horace's lyric poetry: the force of humour. Ramus monographs. Maryborough: Aureal publications.

Davis, G 1991. Polyhumnia. Berkeley: University of California Press.

Dettmer, H 1983. Horace: A study in structure. Hildesheim: Georg Olms Verlag.

Freudenburg, K 1993. The walking muse: Horace on the theory of satire. Princeton: Princeton University Press.

Gowers, E 1993. The loaded table: representations of food in Roman literature. Oxford: Clarendon Press.

Griffin, J 1997. Cult and personality in Horace. JRS 87:54-69.

Harrison, S J (ed.) 1995. Homage to Horace: A bimillenary celebration. Oxford: Clarendon Press.

Hinds, S 1998. Allusion and intertext. Cambridge: Cambridge University Press.

Leach, E W 1994. Horace Carmen 1.8: Achilles, the Campus Martius and the articulation of gender roles in Augustan Rome. CP 89.4:334-343.

Martin, R 2002. Horace in real time: Odes 1.27 and its congeners. In Paschalis Horace and Greek lyric poetry $103-118$.

Oliensis, E 1998. Horace and the rhetoric of authority. Cambridge: Cambridge University Press.

Putnam, M C 1977. Horace Odes 3.9: The dialectics of desire. In Anderson Why Horace? A collection of interpretations 180-194. (Originally published in Ancient and Modern Essays in Honor of Gerald F. Else, 1977, 139-57, Institute for Ancient \& Modern Studies, Ann Arbor, University of Michigan.)

Paschalis, M 2002. Horace and Greek lyric poetry. Rethymnon Classical Studies, 1. Crete: University of Crete, Department of Philology.

Porter, D H 1987. Horace's poetic journey: A reading of Odes 1-3. Princeton: Princeton University Press.

Seager, R 1993. Horace and Augustus: poetry and policy. In Rudd (ed.) Horace 2000: A celebration. Essays for the bimillenium 23-40.

Rudd, N (ed.) 1993. Horace 2000: A celebration. Essays for the bimillenium. London: Duckworth.

Syndikus, H-P 1990. Die Lyrik des Horaz. Eine Interpretation der Oden. Impulse der Forschung 7. Darmstadt: Wissenschaftliche Buchhandlung.

Santirocco, M 1986. Unity and design in Horace's Odes. Chapel Hill: University of North Carolina Press.

Thom, S 1998. Lyric double talk in Horace's Roman Odes (Odes 3.1-6). Akroterion 43:52 - 66.

Van Rooy, C A 1965. Studies in Classical Satire and related literary theory. Leiden: Brill.

Woodman, T \& Feeney, D (eds.) 2002. Tradition and contexts in the poetry of Horace. Cambridge: Cambridge University Press.

Zetzel, J E G 2002. Dreaming about Quirinus: Horace's Satires and the development of Augustan poetry. In Woodman and Feeney (eds.) Tradition and contexts in the poetry of Horace 38-52. 